American Journal of Animal and Veterinary Sciences 2 (1): 23-28, 2007

ISSN $1557-4555$

(C) 2007 Science Publications

\title{
The Effects of Short or Long Term FGA Treatment with or without eCG on Reproductive Performance of Ewes Bred Out-of-season
}

\author{
${ }^{1}$ Mustafa Q. Husein, ${ }^{2}$ Mohammed M. Ababneh and ${ }^{1}$ Dia S. Abu-Ruman \\ ${ }^{1}$ Department of Animal Production, Faculty of Agriculture \\ ${ }^{2}$ Department of Veterinary Clinical Sciences, Faculty of Veterinary Medicine \\ Jordan University of Science and Technology, P. O. Box 3030, Irbid 22110, Jordan
}

\begin{abstract}
The objective was to evaluate the effects of intravaginal FGA sponges inserted for 4 or 12 days with or without eCG on reproductive performance of ewes out-of-season. Forty-eight anestrous ewes were assigned in equal numbers to four treatments in a $2 \times 2$ factorial design. Ewes were administered with FGA sponges on May 17 for 12 days (12-day-FGA-eCG and 12-day-FGA groups, $\mathrm{n}=12$ each) and on May 25 for 4 days (4-day-FGA-eCG and 4-day-FGA groups, $\mathrm{n}=12$ each). All treatments were timed to end together on May 29 (day $0,0 \mathrm{~h}$ ) at which time sponges were withdrawn and eCG or saline was injected. Five fertile rams which had been isolated from ewes were joined at $0 \mathrm{~h}$ for breeding and estrus detection. Blood samples were collected to compare progesterone $\left(\mathrm{P}_{4}\right)$ concentrations and for pregnancy diagnosis. Overall estrus expression occurred in 40/48 ewes which differed only between 12-day-FGA-eCG and 4-day-FGA $(p<0.05)$ groups. Intervals from $0 \mathrm{~h}$ to onset of estrus were shorter $(p<0.05)$ in 12-day-FGA-eCG than those in 12-day-FGA and 4-day-FGA groups with no differences between 12-day-FGA-eCG and 4-day-FGA-eCG or between 12-day-FGA and 4day-FGA groups. Progesterone levels were basal from day -12 through day $4(p>0.1)$ and increased gradually thereafter until day 15 . Progesterone remained elevated through day 19 in $11 / 12,8 / 12,9 / 12$ and 6/12 ewes, respectively, which were diagnosed pregnant on day 30 by ultrasonography. Of the 34 ewes that became pregnant, 31 lambed 150 days following day 0 . Pregnancy loss occurred only in 3 ewes from the two groups that did not have eCG treatment No differences in pregnancy and lambing rates and the number of lambs born were found between 12-day-FGA-eCG and 4-day-FGA eCG. The overall pregnancy and lambing rates obtained from mating at first service were 70.8 and $64.6 \%$, respectively. In conclusion, the 4-day-FGA and eCG regimen could adequately replace the 12-dayFGA out-of-season. Application of such a 4-day-FGA protocol must be accompanied by eCG treatment upon sponge removal.
\end{abstract}

Key words: Awassi ewes, FGA sponges, eCG, Out-of-season

\section{INTRODUCTION}

Estrus synchronization has been practiced for the last few decades, during which time many protocols have been developed. The most widely used protocol was based on the use of intravaginal progestagen sponges inserted for 12 to 14 days followed by eCG at sponge removal and ram introduction ${ }^{[1,2,3]}$. Despite successful outcome implementing such a protocol, reduced fertility rates do still exist in some research studies $^{[4,5,6]}$. Reduced fertility rates have been attributed to many factors including heredity, breed, seasonality, age, environment, nutrition, diseases, semen quality, female reproductive status and hormonal treatment ${ }^{[7,8,9,10,11]}$.

From our prospective, two other interesting factors maybe important. First, the circulating levels of $\mathrm{P}_{4}$ and release during the 12-day period in which pessaries are in place decline over time. Typically, $\mathrm{P}_{4}$ peaks within two days of pessary administration and then deceases gradually with time during the remaining period ${ }^{[6,9,12]}$. Part of the decline in $\mathrm{P}_{4}$ concentrations during the period of insertion maybe due to the wash-out of sponge by the vaginal fluid ${ }^{[13]}$. Therefore, the amount of $\mathrm{P}_{4}$ absorbed and $\mathrm{P}_{4}$ levels at the time of sponge removal in a 12-day treatment may not be sufficient to maintain normal patterns of follicular growth $^{[1]}$. In contrast, $\mathrm{P}_{4}$ in a shorter duration treatment maybe maintained at higher levels, which sensitize follicles to grow in normal patterns. Low $\mathrm{P}_{4}$ concentrations have been associated with formation of persistent follicles, prolonged luteal function and reduced fertility in cattle ${ }^{[14]}$ and

Corresponding author: Dr. Mustafa Q. Husein, Department of Animal Production, Jordan University of Science and Technology, P.O. Box 3030, Irbid 22110, Jordan 
sheep $\left.{ }^{[15}\right]$. Second, the vaginal contamination created following and during the process of sponge insertion. In addition, the use of $\mathrm{P}_{4}$ pessaries for long period is laborious and needs more time to follow-up pessary retention, a treatment that has also been associated with accumulation of offensive vaginal mucus and bad smell upon pessary removal ${ }^{[13]}$.

Our intention was to minimize the period over which progestagen sponges are inserted, from 12-14 days to 4 days only. Short periods of progestagensponge treatment for as little as 5 to 7 days have been reported to be successful in inducing/synchronizing estrus in sheep during both the breeding and out side the breeding seasons ${ }^{[5,16,17,18]}$. Results of McLeod and Haresign ${ }^{[19]}$ demonstrated that $\mathrm{P}_{4}$ priming for as little as 2 days is sufficient to ensure normal luteal function in sheep, but the final stages of follicular growth normally require about 4-5 days. Reducing the period of sponge insertion may maintain higher $\mathrm{P}_{4}$ levels upon removal of pessaries and may reduce the chance of vaginal contamination. Therefore, we hypothesize that the 4-day and 12-day FGA treatments will produce similar reproductive performance of ewes bred out-of-season. The objective of this study was to evaluate the effects of FGA-sponge treatment administered intravaginally for 4 or 12 days with or without eCG on reproductive performance of ewes bred out-of-season.

\section{MATERIALS AND METHODS}

Animal and Experimental Design: Forty-eight, 3 to 5 years old pluriparous Awassi ewes, weighing 47.4 $\pm 5.2 \mathrm{~kg}$ (mean $\pm \mathrm{SD})$ with a body condition score of 2.5 to 3 (scale $=0$ lowest to 5 highest), were used in a study conducted in months of May and June. The experiment was performed at the sheep unit at the Agricultural Center for Research and Production at Jordan University of Science and Technology located in the northern part of Jordan ( $32^{\circ} 33^{\prime} \mathrm{N}$ and $35^{\circ} 51^{\prime}$ E) at an altitude of $510 \mathrm{~m}$. All ewes had previously lambed and had their last lambs been weaned by February 10. During the experimental period, ewes were maintained in a $10 \times 6 \mathrm{~m}$ pen, one-third of which is sheltered and the south wall is open. Ewes were fed $1.0 \mathrm{~kg}$ wheat straw and $0.5 \mathrm{~kg}$ concentrate mixture per ewe per day and trace mineral salt blocks and water were available ad libtum.

Ewes were randomly assigned in equal numbers to four treatment groups in a $2 \times 2$ factorial arrangements. Factors were 1) $40 \mathrm{mg}$ intravaginal fluorogestone acetate (FGA, $40 \mathrm{mg}$, Ceva Animal Health, Ltd, France) sponge inserted for 12 days versus 4 days; and 2) 500 IU equine chorionic gonadotropin (eCG, Ceva Animal Health, Libouurne Cedex, France) injections versus control solutions at the time of sponge removal. Ewes in the 12-dayFGA-eCG and 12-day-FGA groups were administered with sponges on May 17 for 12 days and those in the 4-day-FGA-eCG and 4-day-FGA groups were inserted with sponges on May 25 for 4 days. All treatments were timed to end together on May 29 (day 0 and $0 \mathrm{~h}$ ) at which time sponges were withdrawn and eCG or saline was injected. Five harnessed Awassi rams which had been isolated from ewes were joined upon sponge removal. All animals were run together in a single pen and ewes were checked for breeding marks at 6-h intervals for 5 days. Pregnancy was determined on day 30 using 7.5 $\mathrm{MHz}$ abdominal ultrasound transducer (485 Ansar vet, pie medical equipment B.V, Philipsweg, AJ Maasbricht, The Netherlands).

Blood Sampling and Hormone Assay: A base line blood samples were collected immediately before sponge insertion on day -12 from ewes in the 12-day FGA-treated groups and on day -4 from ewes in the 4-day FGA-treated groups. Blood samples were also collected from all ewes daily between days 0 and 5 , and then on alternate days thereafter until day 19 to compare $\mathrm{P}_{4}$ concentrations among groups and for pregnancy diagnosis. All blood samples ( $5 \mathrm{~mL}$ each) were drawn via jugular venipuncture into heparinized tubes $(5 \mathrm{IU} / \mathrm{mL})$. Blood samples were centrifuged within $30 \mathrm{~min}$ of collection at $3000 \mathrm{~g}$ for $15 \mathrm{~min}$. Plasma was pipetted into $12 \times 75 \mathrm{~mm}$ glass tubes using sterilized plastic disposable pasteur pipettes and then stored at $-20^{\circ} \mathrm{C}$ until assayed for $\mathrm{P}_{4}$ using radioimmunoassay in a single run (RIA, Coat-ACount kit; Diagnostic products corporation, DPC, Los Angeles, CA, USA). Sensitivity was $0.1 \mathrm{ng} \mathrm{mL}^{-1}$ and intra-assay coefficient of variation was $3.1 \%$.

Statistical analysis: Data were analyzed by using SAS/STAT ANOVA procedures ${ }^{[20]}$. Data in text, tables and figures are presented as means \pm SEM, unless otherwise noted. The effects of FGA treatments with or without eCG on incidence of estrus and first-cycle pregnancy and lambing rates were analyzed using the Chi-square test. The effects of FGA treatments with or without eCG on various intervals were analyzed using least-square means of 
the GLM procedures. Onset of estrus was considered to have occurred $3 \mathrm{~h}$ before the observation of the breeding marks. Plasma $\mathrm{P}_{4}$ concentrations were analyzed for the effect of FGA treatment and eCG and time using the repeated-measures procedure of the GLM. The first-cycle pregnancy rate was defined as the number of ewes that became pregnant based upon sustained $\mathrm{P}_{4}$ levels of $>2 \mathrm{ng} \mathrm{mL}^{-1}$ between days 15 and 19 and confirmed on day 30 by ultrasonography and lambed 145-155 days following day 0 .

\section{RESULTS AND DISCUSSION}

Estrus responses: No FGA sponges were lost during the period of insertion. Estrus expression following FGA sponge removal occurred in 40/48 $(83.3 \%)$ ewes, indicating the effectiveness of FGA sponges administered for 4 or 12 days in conjunction with the ram effect in sensitizing ovarian activity and ensuring acceptable estrus expression rate out-ofseason. Estrus was observed in 12/12, 10/12, 10/12 and 8/12 ewes of 12-day-FGA-eCG, 12-day-FGA, 4day-FGA-eCG and 4-day-FGA groups, respectively. Estrus expression rate differed $(\mathrm{p}<0.05)$ between 12 day-FGA-eCG and 4-day-FGA groups. There were no differences between 12-day-FGA-eCG group and 12-day-FGA or 4-day-FGA-eCG and between 4-dayFGA group and 12-day-FGA or 4-day-FGA-eCG (Table 1). The effect of treatment on estrus expression was evident when eCG was incorporated into the synchronization protocol which occurred in $75 \%$ of ewes not receiving eCG and in $91.7 \%$ of ewes when eCG was incorporated. It has been shown that occurrence of estrus in ewes treated with synthetic progestagen in conjunction with eCG varied from 47 to $80 \%{ }^{[21]}$. The absence of estrus in the remaining ewes maybe attributed to inadequate estradiol secretion, maybe reflected by silent estrus since ovulation occurred among all ewes based upon $\mathrm{P}_{4}$ profiles.

Intervals from $0 \mathrm{~h}$ to onset of estrus were shorter $(\mathrm{p}<0.05)$ in 12-day-FGA-eCG $(34.5 \pm 2.6 \mathrm{~h})$ than those in the 12-day-FGA $(42.6 \pm 2.9 \mathrm{~h})$ and 4-dayFGA $(43.5 \pm 3.2 \mathrm{~h})$ groups. The 7 to $8 \mathrm{~h}$ delay in the 12-day-FGA and 4-day-FGA is attributed to the absence of eCG treatment in these two groups. No differences were found in intervals to onset of estrus between the 12-day-FGA-eCG and the 4-day-FGAeCG $(37.2 \pm 2.9 \mathrm{~h})$ or among 12-day-FGA, 4-dayFGA and 4-day-FGA-eCG groups (Table 1). The interaction between eCG and FGA in the time to estrus was significant $(\mathrm{p}<0.01)$. Overall intervals to onset of estrus occurred earlier $(p=0.01)$ in eCGtreated $(35.9 \pm 1.8 \mathrm{~h})$ than non-eCG-treated $(43.1 \pm$ $2.0 \mathrm{~h})$ ewes with no differences $(\mathrm{p}>0.4)$ between the 12-day-FGA $(38.6 \pm 1.8 \mathrm{~h})$ and the 4-day-FGA (40.4 $\pm 2.0 \mathrm{~h}$ ) treated ewes. Shorter intervals in the eCGtreated groups are attributed to the action of eCG on follicular growth by mediating faster pituitary endocrine responses and estradiol secretion. Treatment with eCG has been shown to advance the intervals to estrus and ovulation in sheep ${ }^{[9,22,23]}$. These effects are consistent with gonadotropic action of eCG in sheep ${ }^{[23,24]}$.

Progesterone profile prior to and following sponge removal: Initial plasma $\mathrm{P}_{4}$ concentrations on days $-12,-4$ and on day 0 were basal among groups and averaged $0.1 \pm 0.02 \mathrm{ng} \mathrm{mL} \mathrm{mL}^{-1}$, indicating absence of cyclicity and seasonal anestrus. The present study was conducted in May during which time cyclic activities in Awassi ewes cease ${ }^{[25,26]}$. Similarly, seasonal absence of estrual behavior has been previously reported under similar circumstances ${ }^{[6,27]}$.

After day $0, \mathrm{P}_{4}$ concentrations remained low

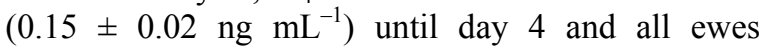
ovulated during this period based upon a subsequent rise in $\mathrm{P}_{4}$ levels. Differences in $\mathrm{P}_{4}$ concentrations between days 0 and 4 were not significant $(p>0.2)$. Progesterone concentrations increased gradually thereafter from day 5 until day 15. Mean plasma $\mathrm{P}_{4}$ concentrations between days 5 and 15 differed $(\mathrm{p}<0.01)$ significantly and were $3.9 \pm 0.2,2.2 \pm 0.1$, $3.4 \pm 0.2$ and $1.9 \pm 0.1 \mathrm{ng} \mathrm{mL}^{-1}$ for the four groups, respectively. Mean values between eCG-treated versus non-eCG-treated ewes and the interaction between eCG and FGA were significant $(\mathrm{p}<0.01)$. Maximum $\mathrm{P}_{4}$ concentrations were reached between days 11 and 15 among ewes of the four treatment groups and were not different between the 4-dayFGA-eCG and the 12-day-FGA-eCG treated groups and between the 4-day-FGA and the 12-day-FGA treated groups (Fig. 1). Pooling data of $\mathrm{P}_{4}$ concentrations indicated differences $(p<0.001)$ between eCG and non-eCG treated ewes with no differences between the 4-day and the 12-day-FGA treated groups without eCG. Higher $\mathrm{P}_{4}$ levels among eCG-treated ewes during this period may largely be attributed to higher ovulation rates and formation of extra corpora lutea due to the gonadotropic activity of $\mathrm{eCG}^{[28,29]}$. 
American J. Animal \& Vety. Sci., 2 (1): 23-28, 2007

Table 1: Reproductive responses following sponge removal in Awassi ewes treated with 12-day-FGA-eCG, 12-day-FGA, 4-day-FGA-eCG and 4-day-FGA.

\begin{tabular}{|c|c|c|c|c|}
\hline \multirow[t]{2}{*}{ Parameter } & \multicolumn{4}{|c|}{ Treatment } \\
\hline & 12-day-FGA-eCG & 12-day-FGA & 4-day-FGA-eCG & 4-day-FGA \\
\hline Ewes exposed & 12 & 12 & 12 & 12 \\
\hline Incidence of estrus ${ }^{1}$ & $12 / 12^{\mathrm{a}}$ & $10 / 12^{\mathrm{ab}}$ & $10 / 12^{\mathrm{ab}}$ & $8 / 12^{\mathrm{b}}$ \\
\hline Onset of estrus $(h)^{2}$ & $34.5 \pm 2.6^{\mathrm{a}}$ & $42.6 \pm 2.9^{b}$ & $37.2 \pm 2.9^{\mathrm{ab}}$ & $43.5 \pm 3.2^{\mathrm{b}}$ \\
\hline Ewes pregnant ${ }^{3}$ & $11 / 12^{\mathrm{a}}$ & $8 / 12^{\mathrm{ab}}$ & $9 / 12^{\mathrm{ab}}$ & $6 / 12^{\mathrm{b}}$ \\
\hline Ewes lambed ${ }^{4}$ & $11 / 12^{\mathrm{ac}}$ & $7 / 12^{\text {ae }}$ & $9 / 12^{\mathrm{a}}$ & $4 / 12^{\text {bde }}$ \\
\hline Lambs born ${ }^{4}$ & $13^{\mathrm{a}}$ & $8^{\mathrm{ab}}$ & $10^{\mathrm{ab}}$ & $5^{\mathrm{b}}$ \\
\hline Fecundity $^{5}$ & $1.08 \pm 0.2^{\mathrm{ac}}$ & $0.67 \pm 0.2^{\mathrm{ab}}$ & $0.83 \pm 0.2^{\mathrm{ab}}$ & $0.42 \pm 0.2^{\mathrm{bd}}$ \\
\hline Prolificacy $^{6}$ & $1.18 \pm 0.1^{\mathrm{a}}$ & $1.14 \pm 0.1^{\mathrm{a}}$ & $1.11 \pm 0.1^{\mathrm{a}}$ & $1.25 \pm 0.2^{\mathrm{a}}$ \\
\hline
\end{tabular}

${ }^{1}$ Number of ewes marked by rams within $72 \mathrm{~h}$ following FGA sponge removal.

${ }^{2}$ Occurring within $72 \mathrm{~h}$ following FGA sponge removal.

${ }^{3}$ Occurring based upon $\mathrm{P}_{4}$ profiles on day 19 and ultrasonography on day 30 .

${ }^{4}$ Ewes lambing and lambs born from mating at first service.

${ }^{5}$ Number of lambs born live per ewes exposed.

${ }^{6} \mathrm{Number}$ of lambs born live per ewes lambing.

${ }^{\mathrm{a}, \mathrm{b}}$ Values within raw with different superscripts $\operatorname{differ}(\mathrm{p}<0.05)$.

${ }^{c, d}$ Values within raw with different superscripts differ $(p \leq 0.01)$.

a,b,c,d,e Numbers or values within row with similar superscript are similar $(\mathrm{p}>0.1)$.

Pregnancy and lambing rates and the number of lambs born: Progesterone remained elevated through day 19 in 11/12, 8/12, 9/12 and 6/12 ewes of 12-dayFGA-eCG, 12-day-FGA, 4-day-FGA-eCG and 4-dayFGA groups, respectively. These ewes were diagnosed pregnant based on ultrasonography on day 30 . Pregnancy rate was higher $(\mathrm{p}<0.05)$ in 12 -day-FGAeCG group than 4-day-FGA group and numerically greater than the 12-day-FGA and 4-day-FGA-eCG with no differences between the 4-day-FGA-eCG and the 4day-FGA groups (Table 1). Progesterone concentrations dropped spontaneously after day 15 in the remaining $1 / 12,4 / 12,3 / 12$ and 6/12 ewes, respectively, and were typical of those seen during normal luteal regression. These ewes were diagnosed non-pregnant based upon ultrasonography.

Of the 34 ewes that became pregnant from mating at first service, 31 lambed $150 \pm 1$ days following day 0 and were $11 / 12,7 / 12,9 / 12$ and 4/12 ewes of 12-dayFGA-eCG, 12-day-FGA, 4-day-FGA-eCG and 4-dayFGA groups, respectively. Pregnancy loss occurred only in 3 ewes that did not receive eCG treatment and were one ewe for the 12-day FGA and two ewes from the 4-day-FGA groups.
Ewes receiving FGA sponges for 12 days had higher overall first service pregnancy $(79.2$ vs. $62.5 \%)$ and lambing ( 75 vs. $54.2 \%$ ) rates than those treated for 4 days, respectively. Likewise pregnancy (83.3 vs. $58.3 \%$ ) and lambing ( 83.3 vs. $45.8 \%$ ) rates were improved in eCG-treated versus non-eCG-treated ewes. The overall pregnancy $(70.8 \%)$ and lambing $(64.6 \%)$ rates obtained in the present study were greater than those (52.2 and $30.4 \%$, respectively) previously reported by Husein and Kridli ${ }^{[6]}$.

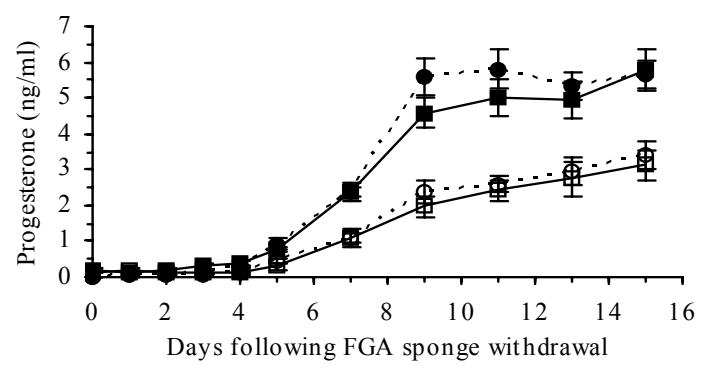

Fig. 1: Plasma progesterone profiles from day 0 until day 15 following FGA sponge withdrawal in Awassi ewes treated with 12-day-FGA-eCG (•), 12-day-FGA (O), 4-day-FGAeCG (ם) and 4-day-FGA ( $\square)$. 
Improved pregnancy and lambing rates among ewes that had FGA sponge for 12 or 4 days and eCG treatment at sponge removal maybe attributed to the incorporation of eCG into the synchronization protocols, since the two FGA regimens produced similar reproductive performance when eCG was used. The use of eCG has been shown to improve reproductive responses of ewes out-of-season ${ }^{[9,30]}$. These observations imply that the administration of FGA-sponge regimen for 4 days out-of-season must be accompanied by eCG treatment. The number of lambs born per ewes exposed was greater $(\mathrm{p}<0.05)$ in 12 -dayFGA-eCG than 4-day-FGA with no differences between 12-day-FGA-eCG group and 12-day-FGA or 4-day-FGA-eCG and between 4-day-FGA group and 12-day-FGA or 4-day-FGA-eCG (Table 1). Fecundity was greater $(p<0.05)$ in eCG-treated than non-eCG treated groups $(0.96 \pm 0.1$ vs. $0.54 \pm 0.1$ lambs $)$. Although the use of FGA sponge alone for 4 days was successful in inducing estrus among ewes, pregnancy and lambing rates and the number of lambs born per ewes exposed were lower in groups treated with FGA alone without eCG than treatments in which eCG was incorporated. The eCG has been widely used estrus synchronization programs and known typically to stimulate ovarian activity and improve fertility rates of the ewe during seasonal anestrus ${ }^{[23,30,31]}$.

Results of the present study are in agreement with those reported previously in the literature ${ }^{[5,16,18]}$. Fitzgerald et al. ${ }^{[5]}$ used $60 \mathrm{mg}$ MAP sponge for 7 days and $20 \mathrm{mg} \mathrm{PGF}_{2 \alpha}$ at sponge removal and were as effective as those obtained using a 14-day MAPsponge treatment. Beck et al. ${ }^{[16]}$ showed that a 5-day $\mathrm{P}_{4}$ treatment and $\mathrm{PGF}_{2 \alpha}$ at sponge removal produced similar results to those obtained using an 8-day $\mathrm{P}_{4}$ treatment without $\mathrm{PGF}_{2 \alpha}$ treatment. More recently, Ataman et al. ${ }^{[18]}$ reported effectiveness of a 7-day-FGAeCG treatment in synchronizing estrus and producing high pregnancy and lambing rates. In contrast, Vinoles et al. ${ }^{[17]}$ claimed that incorporation of eCG into a shortterm progestagen treatment had a deleterious effect on pregnancy rates. Examination of previous data showed that the periods of short-term progestagen treatments varied between 5 and 8 days with successful reproductive performance ${ }^{[5,16,17,18]}$. We have previously reported improved estrus responses and pregnancy rates following a 4-day $\mathrm{P}_{4}$ pretreatment followed by a 5-day GnRH- PGF $_{2 \alpha}$ treatment in ewes bred out-of-season. In addition, follicular growth and maturation in sheep normally require about 4-5 days ${ }^{[19]}$. Therefore, the period of FGA treatment in the present study was reduced to 4 days.
In conclusion, a 4-day intravaginal FGA and eCG at sponge removal regimen can be used successfully in ewes out-of-season. Such treatment was capable of producing reproductive responses similar to those produced by FGA-sponge for 12 days. The use of eCG must accompany application of such a 4-day-FGA protocol out-of-season.

\section{ACKNOWLEDGMENTS}

Authors wish to acknowledge the Deanship of Scientific Research at Jordan University of Science and Technology (JUST) for funding this project (Fund \# $117 / 2005$ ). Authors wish also to express their high gratitude to H. A. Ghozlan and staff led by I. M. Tahat for technical assistance and animal management and care at the sheep unit at the Center of Agricultural Research and Production at JUST.

\section{REFERENCES}

1. Gordon, I., 1975. The use of progestogens in sheep bred by natural and artificial insemination. Ann. Biol. Biochim. Biophys., 15: 303.

2. Hansel, W. and W.E. Beal, 1979. Ovulation control in cattle. Animal reproduction. John Wiley and Sons, New York, pp: 91-110.

3. Zarkawi, M., 2001. Estrous synchronization and twining rate of Syrian Awassi ewes treated with progesterone and PMSG during the breeding season. New Zealand J. Agric. Res., 44: 159-163.

4. Kruip, T. and A.M. Brand, 1975. Follicular growth during the normal cycle and after treatment with progestogens in the ewe. Ann. Biol. Anim. Biochim. Biophys., 15: 191.

5. Fitzgerald, J.A., A. Ruggles, J.N. Stellflug and W. Hansel, 1985. Seven-day synchronization method for ewes using Medroxyprogestrone acetate (MAP) and prostaglandins $F_{2 \alpha}$. J. Anim. Sci., 61(2): 466469.

6. Husein, M.Q. and R.T. Kridli, 2002. Reproductive responses of Awassi ewes treated with either naturally occurring progesterone or synthetic progestagen. Asian-Aust. J. Anim Sci., 15(9): 1257-1262.

7. Beck, N.F.G., M. Jones, B. Davies, A.R. Peter and S.P. Williams, 1996. Estrus synchronization in ewes: The effect of combining prostaglandin analogue with a GnRH agonist (buserelin). Anim. Sci., 62: 85-87.

8. Lewis, R.M., D.R. Notter, D.E. Hogue and B.H. Magee, 1996. Ewe Fertility in the star accelerated lambing system. J. Anim. Sci., 74: 1511-1522. 
9. Husein, M.Q., M.T. Bailey, M.M. Ababneh, J.E. Romano, B.G. Crabo and J.E. Wheaton, 1998. Transcervical artificial insemination of ewes out-of season using frozen-thawed semen Effect of equine chorionic gonadotropin on pregnancy rate. Theriogenology, 49: 997-1005.

10. Webb, R., P.C. Garnsworthy, J.G. Gong and D.G. Armstrong, 2004. Control of follicular growth: local interactions and nutritional influences. J. Anim. Sci., 82: 63-74.

11. Yavuzer, U., 2005. The possibilities of twice yearly lambing of Awassi sheep ewes without using hormones in an organic animal production system. Turk. J. Vet. Anim. Sci., 29: 27-30.

12. Husein, M.Q., M.M. Ababneh, B.G. Crabo and J.E. Wheaton, 1996. Effect of eCG on pregnancy rate of ewes transcervically inseminated with frozenthawed semen outside the breeding season. Sheep Goat Res., 12: 39-45.

13. Wheaton, J.E., K.M. Carlson, H.F. Windels and L.J. Johnston, 1993. CIDR: A new progesteronereleasing intravaginal device for induction of estrus and cycle control in sheep and goats. Anim. Reprod. Sci., 33: 127-141.

14. Thatcher, W.W., R.L. de la Sota, R.L. Schmitt, T.C. Diaz, L. Badinga, F.A. Simmen, C.R. Staples and M. Drost, 1996. Control and management of ovarian follicles in cattle to optimize fertility. Reprod. Fert. Dev., 8: 203-217.

15. Johnson, S.K., R.A. Dailey, E.K. Inskeep and P.E. Lewis, 1996. Effect of peripheral concentrations of progesterone on follicular growth and Fertility in ewes. Dom. Anim. Endocrinol., 13: 69-79.

16. Beck, N.F.G., B. Davies and S.P. Williams, 1993. Estrus synchronization in ewes: the effect of combining a prostaglandin analogue with a 5-day progestagen treatment. Anim. Prod., 56: 207-210.

17. Vinoles, C., M. Forsberg, G. Banchero and E. Rubianes, 2001. Effect of long-term and shortterm progestagen treatment on follicular development and pregnancy rate in cyclic ewes. Theriogenology, 55: 993-1004.

18. Ataman, M.B., M. Aköz and O. Akman, 2006. Induction of synchronized oestrus in Akkaraman cross-bred ewes during breeding and anestrus seasons : the use of short-term and long-term progesterone treatments Revue Méd. Vét., 157(5): 257-260.

19. McLeod, B.J., and W. Haresign, 1984. Evidence that progesterone may influence subsequent luteal function in the ewe by modulating preovulatory follicle development. J. Reprod. Fert., 71: 381-386.
20. SAS Institutes Inc., 1996. SAS guide to personal computers (version $6,4^{\text {th }}$ ed.). SAS Inst. Inc. Cary, NC. USA.

21. Cunningham, N.F., N. Saba, C.D.H. Boarer and J.J.P. Hattersley, 1980. Plasma hormone levels and reproductive behavior in anestrous ewes after treatment with progesterone and PMSG. J. Reprod. Fert., 60: 177-185.

22. Cardwell, B.E., G.Q. Fitch and D. Geisert, 1998. Ultrasonic evaluation for the time of ovulation in ewes treated with norgestomet andnorgestoment followed by pregnant mares serum gonadotropin. J Anim. Sci., 76: 2235-2238.

23. Killeen, I.D. and N.W. Moore, 1970. The effect of pregnant mare serum gonadotropin and human chorionic on ovulation and fertility in the ewes. Aust. J. Agric. Res., 21: 807-814.

24. Papkoff, H., 1981. Variation in the properties of equine chorionic gonadortopin. Theriogenology, 15(1): 3-11.

25. Epstein, H., 19882. Awassi Sheep. World Anim. Rev., 44: 9-18.

26. Epstein, H., 1985. Biology of reproduction, suckling regimes, growth, and development. In: The Awassi sheep with special reference to the improved dairy type. Food and Agriculture Organization of the United Nations, FAO, via delle T. Caracalla. Rome, Italy, pp: 81-140.

27. Husein, M.Q. and R.T. Kridli, 2003. Effect of progesterone prior to GnRH-PGF2 $\alpha$ treatment on induction of estrus and pregnancy of Awassi ewes. Reprod. Dom. Anim., 38: 228-232.

28. Greyling, J.P.C., J.C. Greef, W.C.J. Brink and G.A. Wyma, 1988. Synchronization of estrus in sheep of low-normal mass under range conditions: the use of different progestagen and PMSG. South Afri. J. Anim. Sci., 18: 164-167.

29. Robinson, T.J. and R. J. Scaramuzzi, 1994. Induction of breeding in anoestrous crossbred ewes with progestagen and PMSG with or without prior immunisation against an androstenedione-protein conjugate. Anim. Reprod. Sci., 35(1-2): 57-72.

30. Maxwell, W.M.C., and D.R. Barnes, 1986. Induction of estrus in ewes using a controlled internal drug release device and PMSG. J. Agric. Sci., Cambridge. 106:201-203.

31. Dutt, R.H., 1953. Introduction of estrus and ovulation in anestrual ewes by use of progesterone and pregnant mare serum. J, Anim, Sci., 12: 515-523. 